\title{
SKRINING DAN IDENTIFIKASI BAKTERI TERMOFILIK PENGHASIL SELULASE DAN AMILASE DARI SUMBER AIR PANAS BUKIT KILI SOLOK SUMATERA BARAT DENGAN ANALISIS GEN 16S rRNA
}

\author{
Zona Octarya, Sumaryati Syukur, Endang Purwati RN \\ Program Studi Pendidikan Kimia, Fakultas Tarbiyah dan Keguruan, Universitas Islam Negeri Sultan Syarif \\ Kasim Riau. \\ Program Studi Kimia, FMIPA, Universitas Andalas. \\ Program Studi Nutrisi Ternak, Fakultas Peternakan, Universitas Andalas. \\ Departemen Fisika, Institut Pertanian Bogor
}

\begin{abstract}
ABSTRAK
Enzim termostabil dari bakteri termofilik merupakan enzim yang sangat potensial untuk mengatasi kendala teknis industri yang berhubungan dengan proses pada suhu tinggi. Salah satu sumber enzim adalah mikroorganisme termofilik yang banyak terdapat pada sumber air panas. Indonesia merupakan negara kepulauan yang banyak mempunyai sumber air panas, salah satunya adalah Kabupaten Solok. Penelitian ini mencakup skrining dan identifikasi bakteri penghasil enzim termostabil selulase dan amilase dari sumber air panas Bukit Kili Ketek di Kabupaten Solok. Suhu air panas adalah $52^{\circ} \mathrm{C}$ pada bulan Juni 2009 dan pH air adalah 8. Kultur murni yang diperoleh adalah sebanyak 22 kultur Dari hasil pewarnaan gram, diperoleh sebagian besar bakteri air panas adalah jenis bakteri streptobacilli (basilus) gram positif, hanya dua isolat yang merupakan gram negatif yaitu isolat S1B dan S5B. S2A adalah isolat yang mempunyai aktifitas selulase paling tinggi dibandingkan dari isolat yang lain karena mempunyai indeks zona bening selulase lebih tinggi yaitu 2,6. Isolat S2A juga menghasilkan amilase tinggi dengan indeks zona bening 2,5. Persen identitas bakteri air panas S2A yang diperoleh adalah 97\% dengan Anoxybacillus flavithermus strain AE3.
\end{abstract}

Kata Kunci: Enzim, Bakteri, termofilik, Selulase, Amilase, Anoxybacillus

\section{PENDAHULUAN}

Enzim adalah protein yang mengkatalisis reaksi-reaksi biokimia. Sejumlah enzim dapat digunakan untuk membantu proses industri. Keunggulan utama penggunaan enzim pada proses industri adalah kespesifikan enzim terhadap substrat dan enzim mampu mengurangi konsumsi energi, enzim juga mampu mengurangi konsumsi air dan produk limbah selama proses industri berlangsung. Keunggulan enzim tersebut akan meminimalkan resiko atau dampak proses industri bagi kehidupan manusia dan lingkungan.

Keunggulan enzim dalam aplikasinya di industri menyebabkan kebutuhan enzim dunia semakin meningkat sekitar 7,6\% setiap tahunnya (Puspaningsih, 2007). Peningkatan kebutuhan enzim terutama dipicu oleh makin meningkatnya penggunaan enzim dalam bidang farmasi, kesehatan, dan industri kimia. Beberapa contoh jenis enzim telah diaplikasikan untuk tujuan komersial terutama penggunaannya di industri, yaitu; selulase, hemiselulase, xilanase, amilase, protease, dan lipase.
Penggunaan enzim dalam industri mengalami kendala berhubungan dengan suhu yang tinggi dalam proses industri sehingga dibutuhkan enzim yang stabil dan mempunyai aktifitas yang tinggi pada suhu yang tinggi (enzim termostabil). Enzim termostabil yang ada di pasaran kebanyakan berasal dari bakteri mesofilik dan jamur. Enzim termostabil dari bakteri termofilik merupakan enzim yang sangat potensial untuk mengatasi kendala teknis industri. Kendala lain adalah dalam hal produksi enzim termostabil dari mirkoorganisme termofilik yang sangat rendah. Untuk mengatasi kendala itu, beberapa pendekatan yang telah ditempuh adalah pencarian sumber baru enzim termostabil dari mikroorganisme termofilik yang tumbuh pada habitat yang unik, suhu yang sesuai untuk menghasilkan enzim termostabil dan rekayasa genetika untuk menghasilkan enzim termostabil dengan ekspresi tinggi (Nyoman et al 2007).

Pendekatan dengan mencari sumber-sumber enzim baru dari mikroorganisme termofilik yang diisolasi dari lingkungan unik merupakan 
langkah yang paling memungkinkan untuk dilakukan, karena Indonesia memiliki banyak sumber air panas yang potensial dan unik. Sumber air panas yang ada di Kabupaten Solok sudah dikembangkan sebagai objek wisata dan tempat pemandian, namun belum digali sebagai sumber mikroorganisme termofilik. Kabupaten Solok adalah daerah Propinsi Sumatera Barat yang dilalui oleh Pegunungan Bukit Barisan. Gunung Talang adalah salah satu gunung berapi di Kabupaten Solok yang banyak dijumpai sumber air panas. Lingkungan ini merupakan habitat semua bakteri termasuk diantaranya bakteri termofilik. Beberapa sumber air panas yang ada di daerah Solok berpotensi untuk diketahui keanekaragaman hayati bakteri termofiliknya. Selanjutnya keanekaragaman jenis bakteri termofilik tersebut perlu digali sifat-sifat dan potensi kegunaannya bagi kehidupan manusia terutama dalam bidang teknologi dan industri. Dalam hal ini yang sangat penting adalah untuk mengetahui jenis bakteri yang potensial tersebut dan upaya untuk mengeksplorasinya.

Belum ada yang melaporkan penelitian mikroorganisme termofilik sumber air panas di Kabupaten Solok, sedangkan sumber air panas sangat banyak di Kabupaten Solok, diantaranya yaitu Sumber Air Panas Bukit Kili Barat, Sumber Air Panas Bukit Kili, Sumber Air Panas Sapan dan Sumber Air Panas Bukik Gadang. Semua sumber air panas tersebut mempunyai potensi sebagai sumber mikroorganisme termofilik. Air Panas Bukit Kili Ketek adalah salah satu sumber air panas yang belum ada digali potensi mikroorganismenya.

Dari penelitian sebelumnya, telah diisolasi dan diidentifikasi bakteri termofilik isolat lokal Rimbo Panti (Sevante, 2002) dengan penentuan urutan dan analisis Gen 16S rRNA. Hasil perbandingan dengan program BLAST pada situs NCBI (GenBank) berhasil menunjukkan persen kemiripan terbesar isolat Rimbo Panti dengan Geobacillus Subterraneus strain K (98\%), Geobacillus Steraneus (98\%) dan Bacillus thermodinitrificans (97\%). Isolasi bakteri termofilik aerob yang mempunyai sifat fisik yang unik telah diisolasi dari sumber air panas
Savusavu di Fiji. Produksi enzim hidrolitik dan ekstraseluler (amilase, lipase dan gelatinase) bakteri tersebut diskrining dengan metoda kultur streak bakteri termofilik murni pada nutrient starch agar (NSA), nutrient gelatine agar (NGA), dan nutrient lipid agar (NLA) melalui pengukuran zona bening (Narayan et al 2008). Produktifitas enzim termostabil yang berasal dari isolat bakteri yang lebih potensial dipengaruhi oleh $\mathrm{pH}$, konsentrasi substrat, sumber karbon, sumber nitrogen, vitamin dan asam amino (Bayoumi et al 2007).

Isolasi dan karakterisasi bakteri termofilik baru juga telah dilakukan dari sumber air panas di Jordania. Sistem identifikasi yang digunakan adalah karakteristik biokimia, morfologi dan kondisi pertumbuhan optimal. Hasil analisa sekuens gen 16S rRNA isolat baru yang ditemukan menunjukkan bahwa isolat adalah kelompok baru dari genus Bacillus (Elnasser et al 2007). Salah satu target isolasi bakteri termofilik yang telah dilakukan tersebut adalah untuk memproduksi enzim termostabil.

Nora (2004) mengemukakan bahwa amilase dan selulase semakin banyak digunakan sebagai bahan aditif pada makanan ternak. Tujuan utamanya adalah memperbaiki nutrisi ternak dengan cara mendegradasi kandungan seratnya, hal ini sangat penting bagi ternak berusia muda yang belum mempunyai kemampuan enzim dengan aktifitas tinggi untuk mengolah serat. Berdasarkan alasan komersial, amilase banyak digunakan sebagai food additive, sedangkan selulase mempunyai harga mahal sehingga jarang digunakan sebagai food additive. Dengan alasan ini maka sangat penting sekali mencari sumber enzim selulase dari bakteri termofilik dan mengolahnya menjadi bahan pencampur makanan ternak. Hipotesis untuk melakukan penelitian ini adalah bahwa akan ditemukan jenis bakteri baru pada sumber air panas Bukit Kili Ketek di Kabupaten Solok yang mempunyai kemampuan ekstraseluler enzimatis.

Masih belum digalinya potensi sumber air panas di Kabupaten Solok, khususnya Sumber air panas Bukit Kili Ketek sebagai salah satu habitat mikroorganisme termofilik. Belum ada penelitian yang memaparkan jenis bakteri apa saja yang 
terkandung di dalamnya. Sumber air panas merupakan kekayaan alam yang sangat penting karena berpotensi sebagai sumber mikroorganisme termofilik penghasil enzim termostabil ekstraseluler. Indonesia banyak mempunyai sumber air panas yang merupakan tempat hidup bakteri termofilik dan mempunyai potensial besar untuk menghasilkan enzim termostabil tersebut.

Tujuan penelitian ini adalah untuk mengskrining dan mengidentifikasi bakteri termofilik pada sumber air panas Bukit Kili Ketek di Kabupaten Solok yang mempunyai aktifitas enzimatis ekstraseluler (selulase dan amilase) dengan analisis Gen 16S rRNA serta melakukan karakterisasi molekuler enzim ekstraselulernya.

\section{METODOLOGI PENELITIAN}

Peralatan yang digunakan adalah: petridish, hoki stik, jarum ose, alat-alat gelas, inkubator, autoklav, pipet mikro, timbangan digital, water bath, chemical hood, pengaduk magnet, hotplate stirrer, tabung sentrifugasi, Eppendorf, alat elektrophoresis (Mupid exu), perangkat dokumentasi, freezer, Thermal Cycler PCR system, mikrosentrifus, mikrosentrifus dingin, vortex dan alat-alat gelas laboratorium.

Bahan-bahan yang digunakan adalah: Agarose (Iwai AG 5994), Aquadest, $\mathrm{HCl}, \mathrm{NaOH}$ (Merck), Bacto agar (Himedia), Tryptone, Beef extract, $\mathrm{NaCl}$, Peptone, Yeast extract (Himedia), EDTA, Etanol pa (Merck), Etidium bromida, Sodium dodesil sulfat (SDS), Isopropanol, Tris base, Buffer TBE (Tris Boric acid EDTA) (Takara), Nutrient Broth, Nutrient Agar (Himedia), CTAB (Hexadecyltrimethyl ammonium Bromide) Gram staining solution dari Merck (larutan kristal violet, Safranin, lugol, larutan decolourizing), $\left(\mathrm{NH}_{4}\right)_{2} \mathrm{SO}_{4} 2 \mathrm{~g}, \mathrm{MgSO}_{4}$ -

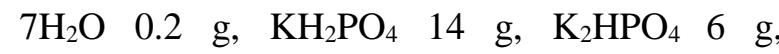
Trisodium sitrat 1,0 g, pati (Merck), CMC (Carboxymethil Cellulosa) (Merck), Congo red, TE (10mMTris-HCl, 1Mm EDTA, pH 7.6), Lysozyme (60mg/Ml), Commasie blue, Larutan destaining (5\% metanol dan 7\% asam asetat), Primer universal 8F dan 1541R (Zainal, 2009),
$\mathrm{ddH}_{2} \mathrm{O}$ (DW), Deoksi Nucleotide Triposphate (dNTPs), taq Polymerase, $10 \mathrm{x}$ buffer PCR.

\section{Isolasi Bakteri Termofilik}

Sampel air panas dikoleksi dari sumber air panas yang ada di Kabupaten Solok, yaitu Air Panas Bukit Kili Ketek yang berukuran 2 m x 1,5 $\mathrm{m}$ dengan menggunakan botol $10 \mathrm{~mL}$ beserta tutupnya dan dimasukkan ke dalam thermal containers (termos) untuk mempertahankan suhunya selama perjalanan ke laboratorium untuk analisa selanjutnya pada hari yang sama. Sampel diambil pada kedalaman $40 \mathrm{~cm}$ di bawah permukaan air, agak jauh dari pinggir. Suhu air panas pada saat diambil adalah $52^{\circ} \mathrm{C}$ dengan $\mathrm{pH}$ 8. Sampel diambil lebih dekat ke mata air agar dapat mewakili suhu yang paling tinggi di kolam air panas tersebut. Bakteri termofilik diisolasi, dikayakan dalam Nutrient Broth dan dimurnikan menggunakan metoda gores pada media NA. Suhu inkubasi yang digunakan adalah $52^{\circ} \mathrm{C}$ selama 24 jam (Nunes dan Martin, 2001).

\section{Uji Gram}

Karakter morfologi bakteri ditentukan dengan menggunakan kultur bakteri murni yang berumur 18 jam di dalam Nutrient Agar. Hal ini mencakup preparasi kultur basah menggunakan mikroskop cahaya. Satu koloni bakteri ditotolkan pada kaca objek yang sebelumnya telah diteteskan $\mathrm{NaCl}$, kemudian diratakan dengan ose membentuk bulatan. Kaca objek dipanaskan sampai $\mathrm{NaCl}$ yang telah mengandung koloni bakteri kering. Diteteskan crystal violet pada objek dan dibiarkan 1 menit, dicuci dan dikover dengan larutan lugol iodin selama 1 menit. Kemudian dicuci dengan larutan decolorizing 4 (aseton) atau 3 (etanol) sampai tidak ada lagi warna ungu yang tersisa. Dicuci dengan aquadest steril selama 5 detik. Kemudian dikover dengan safranin selama 1 menit dan dicuci dengan aquadest steril selama 5 detik. Kaca objek dikeringkan dan dilihat di bawah mikroskop dengan perbesaran 100 kali (Prescot et al, 1990).

\section{Uji Amilase}

Hidrolisis pati diuji di dalam medium nutrient agar yang mengandung $1 \%$ pati. Plate 
diinkubasi pada suhu $52^{\circ} \mathrm{C}$ selama 24 jam. Adanya daerah bening disekitar koloni setelah penambahan Lugol iodin menunjukkan bahwa adanya aktifitas amilase (Elnasser dan Maraqa, 2007).

\section{Uji Hidrolisis Karboksimetil Selulosa (CMCase/ Selulase)}

Untuk menentukan selulosa ekstraseluler ditentukan di dalam medium thermus agar plate $(0,5 \% \mathrm{NaCl}, 0,5 \%$ pepton, $0,4 \%$ beef extract, $0,2 \%$ yeast extract dan $2 \%$ agar) yang mengandung $0,5 \%(\mathrm{w} / \mathrm{v})$ karboksimetil-selulosa (pH 6,5). Kultur diinkubasi 24 jam pada suhu $52^{\circ} \mathrm{C}$. Aktifitas selulase dideteksi dengan Congo red $0,1 \%$ dan $\mathrm{NaCl} 1 \mathrm{M}$. Daerah bening di sekeliling bakteri yang tumbuh yang berlatar merah menunjukkan hasil yang positif (Elnasser dan Maraqa, 2007).

\section{Isolasi DNA Bakteri Termofilik}

Pelet bakteri diperoleh dari sentrifugasi $3 \mathrm{ml}$ kultur DNA yang telah ditumbuhkan semalam di dalam Nutrient Broth cair pada suhu $52^{\circ} \mathrm{C}$. Untuk mendapatkan pelet, $1 \mathrm{ml}$ kultur disentrifugasi dengan kecepatan $13.000 \mathrm{rpm}\left(4^{\circ} \mathrm{C}\right) 5$ menit. Pelet ditambahkan 500 $\mu 1 \mathrm{TE}$, ditambahkan $40 \mu \mathrm{L}$ Lysozyme. Kemudian larutan diinkubasi pada $37^{\circ} \mathrm{C}$ selama 1 jam. Larutan ditambah $200 \mu \mathrm{l}$ $10 \%$ SDS, $100 \mu \mathrm{l}$ of $\mathrm{NaCl} 5 \mathrm{M}$ dan $80 \mu \mathrm{l}$ of CTAB $10 \%$, dipanaskan dalam waterbath $68^{\circ} \mathrm{C}$ selama 30 menit dan dibolak balik tiap 10 menit. Larutan ditambah chloroform 1:1 (v:v) dan disentrifus $13.000 \mathrm{rpm}$ selam 10 menit. Supernatan diambil dan dipindahkan ke Eppendorf baru dan ditambah 0,6 X Isopropanol. Larutan disentrifus $13.000 \mathrm{rpm}$ selama 5 menit untuk memperoleh pelet. Pelet dicuci dengan 100 $\mu \mathrm{L}$ etanol $70 \%$. Pelet dikering anginkan dan kemudian diresuspensi dengan $30 \mu \mathrm{l}$ DW yang mengandung $0.1 \mathrm{mg} / \mathrm{mL}$ RNase dan disimpan pada $-20^{\circ} \mathrm{C}$ (Sambrook et al, 1989).

\section{Reaksi PCR}

Gen 16S rRNA dari genomik DNA yang diisolasi dari koloni bakteri murni diamplifikasi dengan PCR. Reaksi amplifikasi DNA dilakukan dalam thermocycler dengan menggunakan primer
8F (5'AGAGTTTGATCCTGGCTCAG) dan 1541R (5'AAGGAGGTGATCCAGCC). DNA templat yang digunakan adalah $3 \mu \mathrm{l}$ dan dimasukkan ke dalam Eppendorf. Bahan-bahan untuk satu sampel dalam reaksi PCR adalah 39,5 $\mu \mathrm{ldd} \mathrm{H}_{2} \mathrm{O}$, primer $\mathrm{F}$ dan $\mathrm{R}$ masing-masing $0,5 \mu \mathrm{l}$ dan $1 \mu \mathrm{l} 10 \mathrm{mM}$ dNTPs, taq polymerase $0,5 \mu \mathrm{l}$ dan $10 \mathrm{x}$ buffer $5 \mu \mathrm{l}$ dibuat dalam tube $1,5 \mathrm{ml}$. Sebanyak $47 \mu 1$ bahan di atas ditambahkan ke dalam Eppendorf DNA templat. Reaksi PCR adalah sebanyak 35 siklus PCR (denaturasi $96^{\circ} \mathrm{C}$ selama 5 menit, denaturasi berikutnya $96^{\circ} \mathrm{C}$ selama 1 menit, annealing $55^{\circ} \mathrm{C}$ selama 1 menit, ekstensi $72^{\circ} \mathrm{C}$ selama 3 menit dan final extension $72^{\circ} \mathrm{C}$ selama 7 menit). Produk PCR dianalisa pada gel agarose $1 \%$ dan divisualisasi dengan ultraviolet illumination setelah ditambah ethidium bromide. Pita DNA yang diperoleh pada agar dipotong dan dipurifikasi dengan Promega Kit Protocol (Zainal, 2009).

\section{Purifikasi DNA dengan Promega Kit Protocol \\ Pita DNA dipotong dari gel agarose,} dimasukkan gel ke dalam tube dan ditambah 3 kali volume membrane binding solution terhadap volume gel. Campuran diinkubasi pada $50^{\circ} \mathrm{C}$ selama 10 menit. Campuran dimasukkan pada kolom QIAquick dan disentrifugasi $10.000 \mathrm{rpm}$ selama 1 menit pada suhu ruang. Ditambahkan $759 \mu \mathrm{l}$ membrane wash solution dan disentrifugasi $10.000 \mathrm{rpm}$ selam 1 menit pada suhu ruang. Ditambahkan lagi $500 \mu \mathrm{l}$ membrane wash solution dan disentrifugasi lagi $10.000 \mathrm{rpm}$ selama 1 menit pada RT. Kolom QIAquick dipindahkan ke dalam Eppendorf 1,5 baru dan ditambahkan 30-50 $\mu$ l buffer elusi pada bagian tengah kolom QIAquick. Ditunggu 1 menit dan kemudian disentrifugasi $10.000 \mathrm{rpm}$ selama 1 menit (Promega Kit Protocol).

\section{Analisis Data Sekuensing}

Analisis data sekuensing dilakukan dengan menggunakan program software DNA star. Untuk analisa sequence alignment, dilakukan dengan membandingkan sekuens yang diperoleh (query) dengan yang telah ada pada GeneBank menggunakan BLAST (Basic Local Alignment 
Search Tool) pada situs http:/www.ncbi.nl.nih.gov/. Phylogenetic tree dari isolat yang diperoleh dibuat dengan menggunakan ClustalW.

\section{HASIL DAN PEMBAHASAN Isolasi Bakteri Termofilik}

Air diambil sebagai sampel dari sumber air panas Bukit Kili di Kabupaten Solok. Suhu air panas adalah $52^{\circ} \mathrm{C}$ pada bulan Juni 2009 dan $\mathrm{pH}$ air adalah 8. Pengambilan sampel diambil mendekati mata air, yaitu yang mempunyai suhu paling tinggi pada kolam air panas. Hal ini bertujuan untuk mendapatkan bakteri yang hidup disekitar mata air panas dan mempunyai aktifitas enzimatis pada suhu kolam air panas.

Setelah sampel diisolasi dengan metoda pengenceran bertingkat dan diinkubasi selama 24 jam, muncul koloni-koloni bakteri pada plate $10^{-}$ ${ }^{1}, 10^{-2}, 10^{-3}, 10^{-4}, 10^{-5}$ dan $10^{-6}$ (Tabel 3). Dari Tabel 3 dapat diketahui bahwa pada pengenceran $10^{-4}, 10^{-5}$ dan $10^{-6}$ koloni-koloni bakteri telah dapat dihitung karena sudah terpisah dengan baik, sedangkan pada pengenceran $10^{-7}$ bakteri tidak ada yang tumbuh lagi. Untuk menghitung Colony Forming Unit (CFU) bakteri termofilik diambil data pada pengenceran $10^{-4}$ karena memenuhi syarat untuk dihitung yaitu mempunyai jumlah lebih dari 30 koloni. Jumlah bakteri termofilik total sumber air panas Bukit Kili Ketek yang ditemukan adalah $7,9 \times 10^{5}$ CFU's/mL.

Tabel 3. Jumlah koloni bakteri Termofilik.

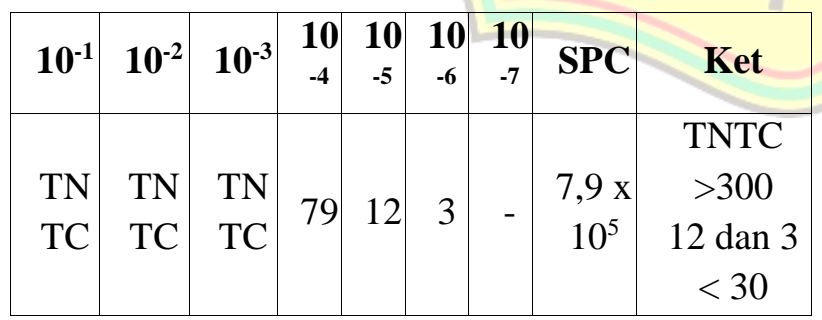

Keterangan: TNTC (Too Numerous to Count), SPC (Standard Plate Count)

Jumlah koloni bakteri yang ditemukan ini lebih banyak dibandingkan dengan yang ditemukan oleh Narayan (2008) di sumber air panas Savusavu Fiji yaitu 2,2 x $10^{4} \mathrm{CFU}$ 's $/ \mathrm{mL}$. Abdelnasser (2007) menemukan jumlah koloni bakteri pada sumber air panas Haman Mesir $2 \mathrm{x}$ $10^{4} \mathrm{CFU}$ 's $/ \mathrm{mL}$ dan tidak ada satupun bakteri yang mampu menghasilkan selulase dengan metoda langsung (direct plating method). Produksi selulase ditemukan setelah dilakukan pengayaan sampel (enrichment step) dengan selulosa selama 4 minggu. Hal ini menunjukkan bahwa sumber air panas Bukit Kili Solok mempunyai lebih banyak mikroorganisme termofilik dan berpotensi menghasilkan enzim ekstraseluler. Jatuhan daun, ranting dan batang dari pohon sekitar sumber air panas merupakan sumber bahan organik yang dapat dimanfaatkan mikoorganisme sebagai sumber karbon, sehingga mikroorganisme yang hidup akan lebih banyak.

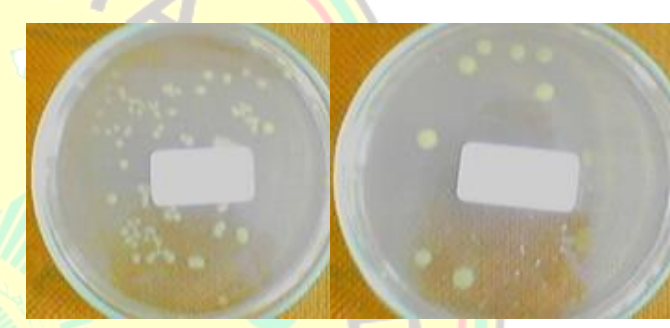

Gambar 6. Bentuk koloni bakteri air panas pada pengenceran $10^{-4}(\mathrm{~A})$ dan $10^{-5}(\mathrm{~B})$

Pada gambar 6, terlihat koloni bakteri air panas yang sudah tumbuh terpisah dengan baik. Bentuk koloni bulat, ukuran bervariasi, berwarna putih dan ada yang putih kekuningan. Pada kultur murni bakteri hanya terdapat satu jenis bentuk koloni bakteri. Kultur murni yang diperoleh adalah sebanyak 22 kultur. Perbedaan dari 22 macam isolat tersebut dibedakan berdasarkan pengamatan morfologi koloni bakteri.

Morfologi koloni bakteri yang ditemukan setelah dimurnikan sangat beragam, bentuknya ada yang sirkular dan iregular, elevasi bakteri ada yang cembung dan datar, permukaannya ada yang halus dan ada yang mengkilap. Bentuk pinggir atau marginnya ada yang bulat penuh (entire), lobate dan berombak-ombak (undulate). Ukuran koloni bakteri ada yang sedang, kecil dan besar.

Untuk mengetahui jenis bakteri air panas yang diperoleh, karakterisasi yang kedua setelah pengamatan morfologi adalah dengan uji gram. 
Pada prinsipnya, uji gram adalah untuk mengelompokkan bakteri berdasarkan reaksi kimia. Uji gram mengelompokkan bakteri menjadi dua, yaitu bakteri gram positif dan bakteri gram negatif. Uji gram yang dilakukan adalah dengan larutan pewarna gram (Gram Stainning). Pada saat sel bakteri ditambahkan pewarna kristal violet, maka sel bakteri akan menyerap pewarna, interaksi antara sel bakteri dengan kristal violet akan semakin kuat dengan ditambahkan larutan iodin. Pada saat dicuci dengan etanol, bakteri gram positif akan tetap mengikat kompleks kristal violet-iodin sehingga menjadi berwarna ungu, sedangkan bakteri gram negatif akan kehilangan kompleks kristal violetiodin karena mempunyai dinding sel yang lebih tipis dan menjadi tidak berwarna. Ketika ditambahkan pewarna safranin, maka bakteri gram negatif akan menyerapnya dan berwarna merah muda sedangkan bakteri gram positif tidak akan menyerap pewarna lagi. Kultur bakteri yang digunakan untuk Gram staining adalah kultur muda yang berumur lebih kurang 18 jam (Prescot et al 1990).

Hasil pewarnaan gram menunjukkan bahwa sebagian besar bakteri air panas dari Air Panas Bukit Kili Ketek ini adalah jenis bakteri streptobacilli (basilus) gram positif, hanya dua isolat yang merupakan gram negatif yaitu isolat S1B dan S5B. Salah satu isolat air panas S2A jenis basilus, gram positif dari hasil pewarnaan gram bakteri yang berwarna ungu ada pada Gambar 7.

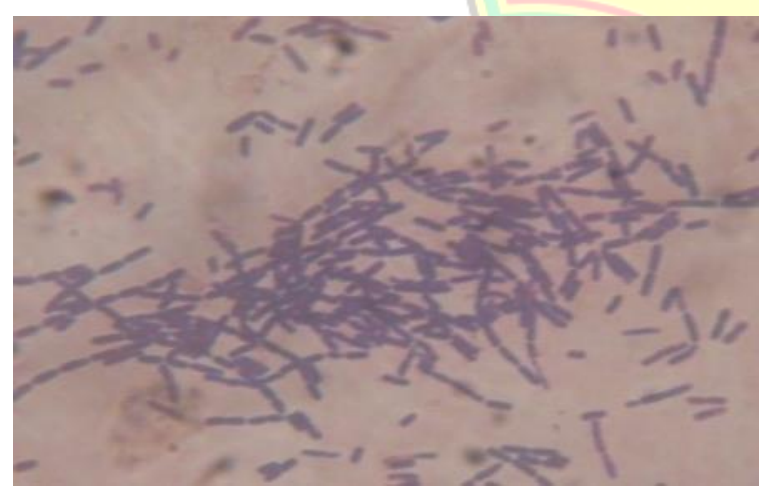

Gambar 7. Foto pewarnaan gram bakteri air panas isolat $\mathrm{S} 2 \mathrm{~A}$

\section{Skrining Bakteri Penghasil Enzim Ekstraseluler}

Pada saat semua isolat bakteri ditumbuhkan dalam medium nutrient starch agar, hanya 7 isolat yang tumbuh dengan menghasilkan zona bening setelah disiram larutan iodin, yaitu S1A, S2A, S4A, S5A, S6A, 48A dan 48B. Hal ini menunjukkan bahwa 7 isolat tersebut menghasilkan enzim ekstraseluler amilase (Gambar 8). Isolat S1A dan S2A menghasilkan indeks zona bening amilase paling tinggi, yaitu 2,5. Molekul pati terdiri dari polimer glukosa yang dihubungkan oleh ikatan $\alpha$ 1-4 dan kadangkadang mempunyai ikatan $\alpha 1-6$, ikatan tersebut dapat dihidrolisis oleh amilase untuk menghasilkan dekstrin, glukosa dan maltosa. Larutan iodin bisa digunakan sebagai indikator ada tidaknya molekul pati karena iodin akan membentuk kompleks berwarna biru kehitaman dengan pati. Munculnya zona bening di sekitar koloni bakteri karena molekul pati telah dipecah oleh amilase sehingga larutan iodin tidak membentuk kompleks lagi dengan pati.
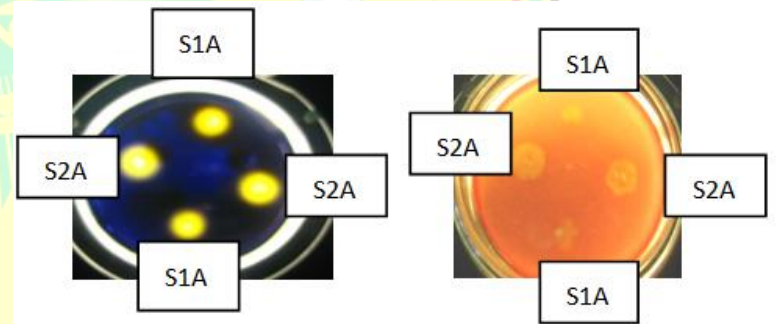

Gambar 8. Isolasi bakteri termofilik penghasil amilase (A) dan selulase (B) yang diinkubasi pada suhu $52^{\circ} \mathrm{C}$ selama 24 jam

Semua isolat bakteri yang ditanam dalam medium CMC menunjukkan aktifitas selulase, karena munculnya zona bening di sekitar koloni bakteri setelah plate disiram dengan congo red dan dicuci dengan $\mathrm{NaCl} 1 \mathrm{M}$ (Gambar 8). Congo red dapat dijadikan sebagai indikator adanya selulosa karena dapat berikatan secara non kovalen dengan serat selulosa (Abdelnasser dan Ahmed, 2007). Dari hasil uji dengan CMC menunjukkan bahwa semua isolat bakteri yang berhasil diisolasi mempunyai kemampuan menghasilkan selulase. 8 isolat yang mempunyai indeks zona bening paling tinggi adalah S1A, 
S2A, S3A, S2A, S5A, S6A, 48A dan 48B. Hal inilah yang menjadi alasan penelitian selanjutnya yaitu untuk mencari isolat bakteri yang mempunyai aktifitas selulase paling tinggi.

Selulase adalah enzim yang dapat menghidrolisis selulosa. Homopolimer selulosa disusun oleh anhydro-D-glucosa yang dihubungkan oleh ikatan $\beta-1,4$ dan merupakan biopolymer yang paling banyak di alam. Degradasi selulosa menjadi glukosa membutuhkan gabungan atau aksi kerjasama 3

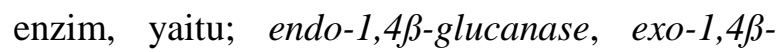
glucanase dan $\beta$-glucosidase. $\mathrm{CMC}$ (Carboxymethyl cellulose) adalah substrat untuk mengetahui aksi enzim endo-1,4 $\beta$-glucanase (Bhat and Bhat 1997). Oleh karena itu, bakteri yang menghasilkan zona bening pada medium CMC tersebut menghasilkan enzim endo-1,4 $\beta$ glucanase (CMCase). S2A adalah isolat yang mempunyai aktifitas selulase paling tinggi dibandingkan dari 7 isolat yang lain karena mempunyai indeks zona bening selulase lebih tinggi yaitu 2,6. Disamping itu, isolat S2A juga menghasilkan amilase tinggi dengan indeks zona bening amilase 2,5.

\section{Identifikasi Bakteri Air Panas S2A dengan Analisis Gen 16S rRNA}

Identifikasi isolat $\mathrm{S} 2 \mathrm{~A}$ sebagai isolat pilihan adalah berdasarkan pada sekuen Gen $16 \mathrm{~S}$ Ribosomal RNA. Gen 16S sRNA adalah subunit ribosom yang dapat digunakan sebagai penanda, pembeda dan sebagai evolutionary marker pada bakteri.

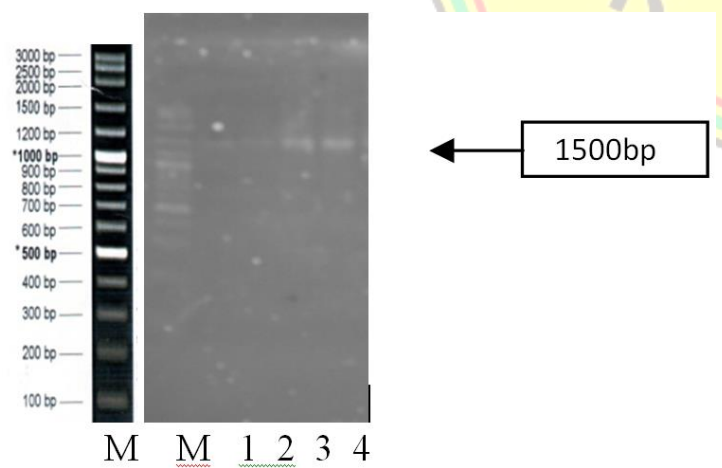

\section{Gambar 9. Isolasi DNA Genomik Isolat S2A}

DNA bakteri yang diperoleh dijadikan templat untuk reaksi PCR. Primer yang digunakan untuk mengamplifikasi DNA adalah:
8F (5'AGAGTTTGATCCTGGCTCAG) dan 1541R (5'AAGGAGGTGATCCAGCC).

Kedua primer ini telah digunakan oleh Liang dan Lungisa (2009) untuk mengamplifikasi DNA bakteri jenis basilus dan menghasilkan produk 1450 bp. Selain itu primer ini juga telah digunakan oleh Youseuf dan kawan-kawan (2009) untuk mengamplifikasi Gen 16S rRNA strain basilus. Hasil amplifikasi PCR gen 16S rRNA isolat bakteri air panas S2A dengan menggunakan primer $8 \mathrm{~F}$ dan $1541 \mathrm{R}$ adalah 1500 bp (Gambar 9 nomor 4).

Hasil penggabungan sekuensing $8 \mathrm{~F}$ dan 1541R dibandingkan dengan data GeneBank melalui program BLAST. Persen identitas bakteri air panas S2A yang diperoleh adalah $97 \%$ dengan Anoxybacillus flavithermus strain AE3, Anoxybacillus sp. SW, Bacillus sp YMY1010 dan Anoxybacillus flavithermus strain $B$ dengan $\mathrm{E}$ value 0,0 . Berdasarkan persen identitas dan $\mathrm{E}$ value yang diperoleh maka untuk identifikasi isolat S2A diambil yang mempunyai persen identitas yang lebih besar dan mempunyai nilai harapan (E value) nol dan query coverage yang lebih besar, maka isolat $\mathrm{S} 2 \mathrm{~A}$ adalah mirip dengan Anoxybacillus flavithermus strain AE3. Isolat ini ditemukan pada Air Panas Geotermal Tunisia (2010) dengan jumlah basa 1524 bp.

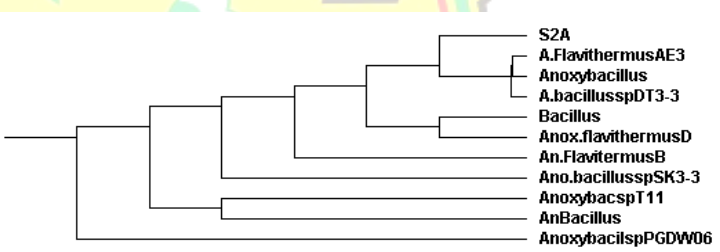

Gambar 10. Filogenetik Isolat Bakteri Air Panas S2A

\section{KESIMPULAN}

Dari penelitian yang telah dilakukan dapat disimpulkan bahwa:

1. Isolat bakteri air panas $\mathrm{S} 2 \mathrm{~A}$ adalah jenis isolat baru yang mempunyai kemiripan $97 \%$ dengan Anoxybacillus flavithermus strain AE3.

2. Isolat bakteri air panas $\mathrm{S} 2 \mathrm{~A}$ mempunyai kemampuan menghasilkan enzim ektraseluler selulase dan amilase dengan 
indeks zona bening masing-masingnya 2,6 dan 2,5.

\section{DAFTAR PUSTAKA}

Abdelnasser, Ahmed, 2007. Isolation and Identification of New Cellulases Producing Thermophilic Bacteria from an Egyptian Hot Springs and Some Properties of the Crude Enzyme. Australian Journal of Basic and Applied Science, 1(4). 473-478.

Bayoumi. Ra, Loubodey, 2007. Production, Purification and Characterization of Thermophilic Lipase for Application in BioDetergent Industry. Journal of Applied Sciences Research, 3(12): 1752-1765.

Bhat, MK dan S. Bhat, 1997. Cellulose Degrading Enzymes and Their Potential Industrial Application. Biotechnol. Adv. 15: 583-620.

Elnasser Ziad, Maraqa A, 2007. Isolation and Characterization of New ThermophilicBacteria in Jordan. The Internet Journal of Microbiology. Vol 3. No.2.

Nora.S et al, 2004. Cellulase Fermentation an a novel substrate and Subsequent Utilization of Home-Produced Cellulase and Commercial Amylase I Rabbit Feeding Trial. Science Direct. Vol 20. Issue 1. 49-57.
Nunes. A, Martin, 2001. Isolation, Properties and Kinetics of Growth of Thermophilic Bacillus. Brazillian Journal of Microbiology. 32: 271-275.

Nyoman Tika, Redhana, Ristiati, 2007. Isolasi enzim Lipase Termostabil dari Bakteri Termofilik Isolat Air Panas Banyu Wedang Kecamatan Gerogak Buleleng Bali. Akta Kimia. Vol 2.No: 109-112.

Prescot, Harley, Klein, 1990. Microbiology. Second edition. WCB Publisher. England.

Puspaningsih N, 2007. Enzim Fibrolitik: Manfaat dan Prospek Pengembangannya. FMIPA. UNAIR.

Sambrook. J, Fritsch, Maniatis, 1989. Molecular Cloning. A Laboratory Manual.Edisi Kedua. Cold Spring Harbor Laboratory Press.

Sevante Arreneuz, 2002. Identifikasi Bakteri Termofilik Isolat Rimbo Panti dengan Penentuan Urutan dan Analisis Gen 165 $r R N A$. Jurusan Kimia. Program Pascasarjana Universitas Andalas.

Yoseuf K, Khodadady, Ganjidoust, Badkoubi, Amoozegar, 2009. Isolation and Characterization of a Novel Native Bacillus Strain Capable of Degrading Diesel Fuel. International Journal of Environment and Science Technology. 6(3): 435-444. 